\title{
Commercial Migration Intermediaries and the segmentation of skilled migrant employment
}

Keywords: skilled migration; commercial intermediaries; labour market segmentation

\section{Author details:}

Corresponding author:

Di van den Broek, Work and Organisational Studies, Business School, University of Sydney, Sydney NSW, 2006. Email diane.vandenbroek@sydney.edu.au

Second author:

Will Harvey, University of Exeter, Streatham Court, Rennes Drive, Exeter, EX4 4PU, UK. Emailwilliam.harvey@exeter.ac.uk

Third author:

Dimitria Groutsis, Work and Organisational Studies, Business School, University of Sydney, Sydney NSW, 2006. Email dimitria.groutsis@sydney.edu.aul

\footnotetext{
Abstract

Like all migration, skilled migration depends on intermediary operators that provide services that assist the mobility, labour market entry and integration of migrant workers. However within what is a relatively disparate body of literature on migrant work, there is often either a complete neglect, or only fragmented acknowledgement and analysis of how migration intermediaries influence migrants' access to destination labour markets. By re-engaging with the literature on skilled migration, we highlight the importance of new theorising and empirical investigations into the labour market implications of intermediary activities, which at present remain poorly understood. Most particularly, this article highlights how migration intermediaries shape recruitment, selection and placement, thereby in part determining labour market outcomes for particular groups of migrant workers.
} 


\section{Introduction}

Skilled migrants, particularly those moving from developing to developed economies, are now much more globally mobile than in previous decades. Skilled, and demand-driven mobility has particularly increased in areas of high demand, such as health and related care occupations where ethnic and gender segmentation can be extremely high (Bach, 2007; Dumont et al., 2007; Franck and Spehar, 2010; Connell, 2010). However, while our knowledge of migration flows in these in-demand occupations has improved (Urry, 2007; IOM, 2008; Castles et al., 2012), we know much less about how labour market intermediaries shape the labour market outcomes of such groups as compared to their less skilled counterparts (Forde and Mackenzie, 2010; Martin, 2011; Vosko, 2011; Mackenzie et al., 2012; Fudge, 2012; Lindquist, et al., 2012; Findlay et al., 2013; Groutsis et al., 2015). Perhaps due to their more skilled status, there has been less attention on how intermediaries shape the mobility decisions and labour market outcomes of skilled migrants (Beaverstock, 1996; Salt and Stein, 1997; Yeoh and Willis, 2005; Kynsilehto, 2011; Papademetriou and Sumption, 2013). As recently noted with respect to unskilled mobility:

'Although much is known about why migrants leave home and what happens to them upon arrival, considerably less is known about the forms of infrastructure that facilitate their mobility...(that is)...the institutions, networks and people that move migrants from one point to another...(this)..."black box" in migration research....is generally not scrutinized in this process, but rather taken for granted' (Lindquist et al., 2012: 8-9).

Indeed it is precisely these important 'forms of infrastructure' that requires more critical analysis and debate within the academic literature. While rarely the focus of detailed research, the range of intermediary behaviour is reflected in descriptions of intermediaries as 
migration 'merchants' (Kyle and Liang, 2001: 4; Connell and Stillwell, 2006); 'predatory princes' and 'princely peddlers' (Xiang, 2012). These terms highlight the clear realignment in the nature and the role of intermediaries that service the shifts in migration flows as identified above. As Lindquist et al., (2012) highlight, migration 'brokers' and migration 'networks' may often overlap, therefore migration intermediaries are defined here broadly as agents that intervene at various critical junctures to connect the migrant to the destination country labour market (Groutsis et al., 2015).

Most significantly, the more commercial (re)orientations of migration intermediaries has meant that many private operators offer package deals that might include loans, transportation services, housing advice as well as negotiating employment contracts and assistance with visa documents (Goss and Lindquist, 1995; Findlay and Li, 1999; Coe et al., 2010). As elaborated below, there is much variation in the quantity and quality of services provided and the financial exchanges undertaken, including the existence of any potential loan arrangements. However, given the opaque nature of these intermediary exchanges, many of these differences in service provision are often not readily identified. Further, perhaps due to perceptions that skilled migrants are more autonomous and economically independent, there has been limited examination of the impact of networks of commercially-driven intermediaries which operate at the professional end of the migration spectrum. While commercial intermediaries that service skilled mobility are not entirely new, the increasing demand-driven (i.e. employer-sponsored) nature of skilled migration has propelled their significance. Indeed reports indicate that governments and employers can pay recruitment agents up to $\$ 10,000$ for each skilled migrant worker placed in Europe and the Unites States (Nyberg Sorensen and Gammeltoft-Hansen, 2013: 9).

This exponential growth of intermediaries, their transformation in form and function, and the implications for skilled migrants, dictates the need to focus more specifically on how 
intermediary activities might shape labour market outcomes for skilled migrant workers (Purcell et al., 2004; Davidov, 2004; Peck et al., 2005; Anderson, 2010; Brown, 2011; Manpower Group, 2012). While intermediaries have always been important conduits of global mobility (Tilly, 1990; Poros, 2001; Beaverstock, 2002; Curran and Rivero-Fuentes, 2003; Flum and Cinnamon, 2011; Groutsis et al, 2015), we know less about how commercial intermediaries steer migrants into specific geographic, national and local labour markets (Massey and Espinoza, 1997; Peck and Theodore, 2001; Portes, 1995; Purkayastha, 2005). These issues are as important for skilled migrants as they are for unskilled migrants.

Accumulated, but fragmented, evidence suggests that fundamental transformation in the governance structures surrounding the migration industry broadly and, migration intermediaries specifically has led to a greater commercialisation, and decentralisation of services that are not just facilitating greater migration flows, but also attracting and mediating migration pathways in more interventionist, however less transparent, ways (Benner, 2003; Lindquist et al., 2012; Gammeltoft-Hansen and Nyberg Sorensen, 2013; Menz, 2013; Groutsis et al., 2015). Such developments underscore a need to re-engage with the literature on migration intermediaries to refocus attention on the increasingly marketdriven approaches to migrant recruitment and placement, and the implications of these developments on labour market segmentation. In order to undertake this reassessment, the following section outlines one of the main drivers of the intermediary industry, that is, the trend to more demand-driven migration in many OECD countries. This is followed by a discussion of evidence highlighting the important role of intermediaries in shaping labour market outcomes. 


\section{Skilled and 'Demand-Driven' Mobility}

Migration movements between the major sending and receiving continents up until the 1970s involved flows of unskilled migrants encouraged by nation building or family unification initiatives. However, more recently the trend has re moved away from permanent settlement based on colonial and cultural ties, to 'demand-driven' and temporary migration schemes as evident within most OECD countries (Wright 2012) These demand-driven schemes have allowed employers, rather than government or supra-national agencies, to shape the entry and location of migrant workers (Dustmann and Weiss, 2007; Newland and Agunias, 2007; Chaloff and Lemaître, 2009; Standing, 2009; Baubock, 2011). For example, demand-driven schemes operate in the United Kingdom (Tier Two visa), USA (H-1B visa), Canada (Temporary Foreign Worker Program and Canadian Experience Class), Germany (Green card system), Sweden (employer-sponsored worker scheme) as well as Australia (Temporary Skilled 457 visa scheme) (Papademetriou et al., 2008; OECD 2013; Government of Canada, 2014; Emilsson et al., 2014). Notwithstanding nation-specific differences, these schemes generally provide migrants with fixed-term visas, which are tie them to specific employers and occupations (McLaughlan and Salt, 2002; Cully, 2011; Wright, 2012; Groutsis et al, 2015).

While temporary employer sponsored migration policy plays a major part in shaping labour market outcomes, intermediaries either engaged by employers or working independently of them, are also instrumental in providing important information and services that shape labour market entry, employment opportunities as well as information regarding worker rights and entitlements in destination countries (Forde and MacKenzie, 2009; Ghosh, 2009; Connell, 2010: 79; Sporton, 2013; van den Broek et al 2013). As already outlined, while many of these activities often play out behind the scenes, there is growing evidence that migration intermediaries play a critical role in the way migrants source information about individual 
employment opportunities and destination labour markets. As van Hear (2004) notes, patterns and impacts of migration are shaped by available access to network based resources (or as he terms it, 'capital') that shape the 'hierarchy of destinations that can be reached by migrants' (2004: 3). This is problematic for migrant workers who have less knowledge, language skills or local ties in destination countries, which economists refer to as 'location-specific capital' (DaVanzo, 1980), because it makes them more dependent on support from third parties. Such dependencies in turn makes migrant workers more susceptible to exploitation and likely to gain employment in areas which require lower levels of qualifications and skills compared to their prior training, a phenomenon popularly referred to as 'brain waste' (Salt, 1983; Forde and MacKenzie, 2009; Ciupijus, 2011; Brynin and Güveli, 2012).

\section{Building migrant capabilities or merchandising (mis)information, and reinforcing ethnic stereotypes?}

This 'paradigmatic shift' towards private-sector provision of migration services and information outlined above, has been a universally adopted 'game changer' (GammmeltoftHansen and Sorensen, 2013; Menz, 2013: 109). As indicated earlier, intermediaries driven by a business-case approach overlap at a variety of stages in the migration process; operate in both origin and destination countries; and, intervene at important junctures of the migration process including during negotiations over employment and living conditions 'when power asymmetries between actors can lead either to a mutually beneficial relationship or to exploitation' (Agunias, 2012: 2). While it may be misleading to generalise about the activities of commercially-driven intermediaries, their impact on skilled migrants are decidedly mixed. Looking particularly at the hyper mobile nursing workforce, Buchan et al.'s (2005) research provides some insights into how intermediaries service the needs of global health workforce shortages. Their survey of 380 UK-based migrant nurses (most of whom trained in the Philippines, Nigeria and South Africa) found that two-thirds were recruited through a 
recruitment firm that had ethno-specific cost demands. For example, while $78 \%$ of (English speaking) nurses from Australia, New Zealand and the USA reported they did not have to pay for any services provided by agencies, $74 \%$ of the Filipino, Indian, Pakistani and Mauritian nurses reported that they had paid for these services. The most commonly reported payments included direct fees to the recruitment intermediary; adaptation fees to the Nursing and Midwifery Council (in the United Kingdom) and transport fees required to take up the position with their employer (Buchan et al., 2005: 9-10). Such ethno-specific and variable costs are significant not just because pay structures appear discriminatory, but because there was also evidence that these groups 'also accept less than ideal work and living conditions once at destination'. This is particularly the case in highly competitive labour markets such as the Middle East (Agunias, 2012: 1), or in countries such as Australia where a two-step migration process (i.e. from temporary to permanent migration) depends on positive references from sponsoring employers (Hawthorne, 2012: 51).

A similar, Australian, survey of migrant nurses was administered by the global trade union federation: Public Services International (PSI). This survey indicated that over a third of the 478 employer-sponsored respondents found employment through recruitment agencies based in Australia, their country of origin, or international recruitment agencies. Of those recruited through these agencies, more than one-quarter stated that recruitment had been unethical, meaning that recruitment practices involved limited or inaccurate information about terms and conditions of employment or health and housing information, as well as hidden costs associated with the services provided (Pillinger, 2012; Neerup, 2013; van Hear, 2004; Groutsis et al., 2015).

Further, on arrival migrants surveyed reported that their employment conditions and employment status did not match information supplied by their intermediaries. For example, one nurse respondent in the above survey explained: 'I never get to choose the shift I want, I 
do the unpopular shifts and I don't want to cause trouble as I am tied to my employer and don't want to risk losing my job' (Pillinger, 2012: 28). Nearly one-third of respondents of this study reported similar issues related to their inability to complain, to seek recourse regarding their post-migration experience, and mismatched expectations particularly where visas were based on employer-sponsorship (Pillinger, 2012: 30). These studies reveal the pivotal role played by migration intermediaries in shaping the nature of: segmented cost structures and incidences of misinformation, or at worse deception, about the nature of the employment and post-arrival living conditions in the destination country (Salt and Stein, 1997: 484; Byl, 2010: 96; Neerup, 2013).

Given the paucity of research into intermediary activities, it is difficult to assess how widespread these unsatisfactory brokering practices may be in other occupational sectors. However these studies do suggest that while many intermediaries may build migrant capabilities through the provision of valuable information and services that improve human development and employment opportunities (Agunias, 2009: 10), others provide inadequate and inaccurate information about working and living conditions which can undermine employment opportunity and limit these workers to under-performing labour markets. There is also evidence that those most exposed to poor information (i.e. those from non-English speaking countries) may be the most disadvantaged or desperate migrants eager to leave their home country for better opportunities abroad (van Hear, 2004; Cerna, 2010). As Neerup (2013) notes:

factors such as impoverishment, lack of employment opportunities, and limited access to resources may constrain migrants' options of staying or may convince potential migrants to enter an unfavourable agreement. It is often questionable how well migrants are informed when actual recruiting takes place due to a lack of transparency in the recruiting and contract process. All of the above could thus leave 
migrants in a relatively weak bargaining position when entering contracts (2013: 9091).

Building on a recognition of the importance of intermediaries firstly providing quality and accurate information, the second issue which requires further investigation is how intermediary activities might explicitly channel migrants into certain occupations and areas of the labour market. In Sweden for example, unskilled migrant labour is channelled into different occupations through 'ethnic recruitment networks'. For example, research shows that agricultural workers are sourced from Thailand, housekeeping and restaurant workers from China and information technology workers from India (Woolfson et al., 2013: 9). Sporton's (2005) research on Eastern European migration also indicates how international recruitment agents often explicitly place migrants into under-performing local labour markets, while Bludau's (2011) research indicates how Czech recruitment firms 'created migrant products', in this case nurses hoping to secure employment abroad (2010). These agencies achieved this by making their own assessments of the nurse's personalities and English language skills. Such selections involved recruiters making important decisions about which hospital received which candidate's file, with nurses themselves given limited options to influence the types and location of jobs they applied for, or ended up with. Unsurprisingly, Bludau concludes that recruitment processes were designed to 'run like a well-oiled machines and nurses are simply the cogs' (2011: 102-103).

While intermediaries can build migrant capabilities through the provision of important information and services that improve employment opportunities, as indicated above, others may funnel migrants into under-performing areas of the labour market (Andall, 2000; Agunius, 2009:10). In many respects the role of migration intermediaries in international migration has become the ultimate global business, operating across a range of occupations, sectors and countries (van Hear, 2004; Salt and Stein, 1997; Garapich, 2008; Gammeltoft- 
Hansen and Nyberg Sorensen, 2013; Groutsis et al., 2015). While it is more likely to be lowskilled migrant workers who may be more exposed to unscrupulous intermediaries and concomitant precarious work, there is growing evidence that skilled migrants, particularly those migrating from non-English to English speaking countries, also experience downward mobility due to the inaccurate information provided by, and ethnic stereotypes employed by, migration intermediaries in their dealings with migrants (Lindquist, et al., 2012; Groutsis et al., 2015).

\section{A Way Forward: Regulation and Monitoring of Intermediaries}

Intermediaries play an important role in enabling the increased circulation of both low and high skilled, migration. While they now offer a greater range of services and more 'choice', they also play a more important role in building the labour market opportunities of migrants. As such, there could be more debate about the need to develop tighter regulation to both minimise the cost, but also monitor the activities of these 'agents of human development' (Agunius, 2009: 2). While recognising that there is a wide variation in what countries define as 'skilled' migrants, there is an equally wide variation in the quality and the regulation of intermediary activities including their role in the recruiting, selecting and placcing migrant workers. The salience of understanding how intermediaries recruit and place the growing number of skilled migrants is therefore particularly important as a policy priority. For example, migrants and most particularly employer sponsored migrants, are by their very migration status more vulnerable because they are restricted from free movement between employers; and, their ability to join trade unions is constrained particularly when compared to local workers (Carens, 2003: 108). As such, temporary employer sponsored migrants may be exposed to downward mobility when intermediaries fail to provide reliable and dependable information about working and living conditions. They may not question the exploitative recruitment processes and working conditions that they experience because their employment 
status still represents a better alternative than staying in their home country (Jokinen et al., 2011: 126-129). Migrants may also depend upon a favourable employer reference to transfer from temporary to permanent residency status in the destination country. As such, addressing the regulation of migration intermediaries may also contribute to the better enforcement of labour standards in receiving countries.

Just as immigration law tests international instruments designed to protect migrant workers against precarious employment practices, so too should intermediary activities be regulated and monitored to assess their role in developing or undermining human potential and labour market opportunity (Fudge, 2012: 96; Cangiano and Walsh, 2014). Two options to minimise illegal or adverse intermediary activities could include firstly the provision of more government or mediated, or non government intermediary services, and secondly regulation of the industry could be more consistent and broadranging. With respect to the latter, preliminary research suggests considerable variation in the way intermediaries are regulated even amongst developed economies and long-standing countries receiving migrants. For example, the Canadian province of Manitoba has established a highly regulated framework that effectively minimises recruiter exploitation (Fudge, 2012: 118) whereas in many other Canadian provinces, individual migrants are expected to self-report any infringement of employment standards and the actions of unscrupulous migration intermediaries (Fudge, 2012: 119).

Similarly, concerns over the recruitment processes of health professionals hired through agencies have prompted greater regulation of recruitment agencies in many OECD countries. Some countries (including Australia, Italy, Netherlands, Poland and the United Kingdom) have regulated the use of recruitment agencies for health professionals (Zurn and Dumont, 2008) guided by an ethical code of practice which restricts the recruitment of health workers 
from agencies that do not comply with the World Health Organisation's (WHO) Code of Practice for both domestic and international recruitment (WHO, 2006: 71).

However, even in countries where regulation appears extensive on paper, the issue of enforcement remains problematic. Despite strong regulatory frameworks in some countries, only a minority of potential cases of recruiter mistreatment might be reported due to a lack of awareness about the regulations, a lack of documentation and proof of mistreatment, recruiter dependence on engaging unregistered subcontractors, and prosecution levels being low even when complaints are made (Taylor-Nicholson, 2014a).

Furthermore, and most importantly formal and legal intermediaries may depend on unlicensed informal brokers with strong connections to more remote areas that represent key sources of migrant labour (Lindquist, 2012). In other words, intermediaries in core economic hubs are often using intermediaries to source labour in peripheral economic regions. This weak link between regulated and unregulated intermediaries is therefore an important area for further investigation. For example, some recruiters may not be penalised for using unregistered migration agents despite the fact that unregistered agents themselves may be penalised for operating illegally (Taylor-Nicholson, 2014b). Such regulatory inconsistencies mean that intermediary exploitation is likely to continue in an irregular pattern across geographic regions with dangerous outcomes for particular groups (Yamamoto, 2008; Agunias, 2009: 35; Fudge, 2012: 108).

The systematic regulation of intermediaries is not easy given that regulatory regimes differ across national jurisdictions. Similarly political pressures for deregulation and the primacy of the market will encourage the proliferation of more commercially orientated intermediaries (Groutsis et al., 2015). However despite the difficulties, further research could analyse and investigate the possibility of both supranational and national frameworks that better regulate 
and monitor intermediary activities, and, penalise unscrupulous operators (Agunias, 2012). Indeed it is ironic that while we have international governance structures that regulate global trade, we have limited regulation around the global trade of labour. Regulation could involve greater scrutiny of sub-contractors arrangements in the formal sector in both source and destination countries; and regulating relations between governments, employers, recruiters and other migration agents.

While it may be optimistic to imagine that migration processes will ever be completely free of illegal and or unscrupulous operators, more research could highlight the strategic role of intermediaries in building and/or eroding migrant capabilities in both sending and receiving countries. This article therefore represents an important springboard from which to develop multi-disciplinary theorising and grounded empirical research that advances debate about how commercial migration intermediaries segment labour markets.

\section{Acknowledgements}

The authors would like to thank the three anonymous referees and the editors of this journal for helpful comments on earlier drafts.

\section{References}

Agunias DR (2009) Guiding the Invisible Hand: Making Migration Intermediaries Work for Development. United Nations Development Programme Human Development Reports. Research Paper 2009/22.

Agunias DR (2012) Regulating private recruitment in the Asia-Middle East labour migration corridor. Migration Policy Institute. Issue number 4. Url: http://publications.iom.int/bookstore/free/MPIIssue4_31July2012_web.pdf

Anderson B (2010) Migration, immigration controls and the fashioning of precarious workers. Work, Employment and Society 24(2): 300-317. 
Andall, J. (2000) Gender, migration and domestic service. Aldershot: Ashgate.

Bach S (2007) Going Global? The Regulation of Nurse Migration in the UK. British Journal of Industrial Relations 45(2): 383-403.

Ball R (2004) Divergent development, racialised rights: globalised labour markets and the trade of nurses: The case of the Philippines. Women's Studies International Forum. 27: 119133.

Bauböck R (2011) Temporary Immigrants, Partial Citizenship and Hypermigration Critical. Review of International Social and Political Philosophy 14: 665-693.

Beaverstock JV (2002) Transnational elites in global cities: British expatriates in Singapore's financial district. Geoforum 33(4): 525-538.

Bludau, H. (2011) Producing Transnational Nurses: Agency and subjectivity in global health care labor migration recruitment practices. Anthropology of East Europe Review, 29(1), 94108.

Boyd M, Grieco E (2003) Women and Migration: Incorporating Gender into International Migration Theory. Available at: http://www.migrationinformation.org/Feature/print.cfm?ID=106

Breugel I (1996) The trailing wife: A declining breed? Careers, geographical mobility and household conflict in Britain, 1970-1989. In: Crompton, R, Gallie, D and Purcell K (eds) Changing forms of employment: Organisations, skills and gender. London: Routledge, 235258.

Brown P, Lauder H and Ashton A (2011) The Global Auction: The Broken Promises of Education, Jobs, and Incomes. Open University Press: USA. 
Brynin M, Güveli A (2012) Understanding the ethnic pay gap in Britain. Work, Employment and Society 26(4), 574-587.

Buchan, J., Parkin, T., Sochalski, J., \& World Health Organization. (2003) International nurse mobility: trends and policy implications/by James Buchan, Tina Parkin, Julie Sochalski.

Buchan J, Kingma M and Lorenzo FM (2005) International migration of nurses: trends and policy implications. International Council of Nurses: Geneva.

Byl, Y. (2010) Temporary foreign workers in Canada: A disposable workforce?.Canadian Issues/Thèmes Canadiens.

Cangiano, A., and Walsh, K. (2014) Recruitment processes and immigration regulations: the disjointed pathways to employing migrant carers in ageing societies. Work, Employment \& Society, 28(3): 372-389.

Carens, J. H. (2003) Who should get in? The ethics of immigration admissions. Ethics \& International Affairs, 17(01), 95-110.

Castles, S., Cubas, M. A., Kim, C., \& Ozkul, D. (2012) Irregular Migration: Causes, Patterns, and Strategies. In Global Perspectives on Migration and Development (pp. 117-151). Springer Netherlands.

Cerna, L. (2010) Policies and Practices of Highly Skilled Migration in Times of the Economic Crisis. International Migration Programme, International Migration Papers No. 99. Geneva: 620 International Labour Organisation.

Chaloff J, Lemaître G. (2009) Managing Highly Skilled Labour Migration: A Comparative Analysis of Migration Policies and Challenges in OECD Countries. OECD Social, 
Employment and Migration Working Papers 79. Available at: http://dx.doi.org/10.1787/225505346577

Curran S, Rivero-Fuentes E (2003) Engendering immigrant networks: the case of Mexican migration. Demography 40(2): 289-307.

Coe NM, Jordus-Lier DC (2010) Constrained agency? Re-evaluating the geographies of labour. Progress in Human Geography 35(2): 211-233.

Connell J (2010) Migration and the Globalisation of Health Care. Cheltenham: Edward Elgar. Connell J, Stilwell B (2006) Merchants of medical care: Recruiting agencies in the global health care chain. Merchants of labour 239.

Cully, M. (2011). Skilled migration selection policies: recent Australian reforms. Migration Policy Practice, 1(1), 4-7.

DaVanzo, J. (1981) Repeat migration, information costs, and location-specific capital. Population and environment, 4(1): 45-73.

Davidov G. (2004) Joint Employer Status in Triangular Employment Relationships. British Journal of Industrial Relations 42(4): 727-746.

Dumont JC, Martin JP and Spielvogel G (2007) Women on the Move: The Neglected Gender Dimension of the Brain Drain. The Institute for the Study of Labor (IZA) Discussion Paper No 2920 July.

Dustmann C, Weiss Y (2007) Return migration: theory and empirical evidence from the UK. British Journal of Industrial Relations 45(2): 236-256.

Emilsson, H., Magnusson, K., Osanami Törngren, S., \& Bevelander, P. (2014) The world's most open country: labour migration to Sweden after the 2008 law. 
Findlay, A. M., \& Li, F. L. N. (1999) Methodological issues in researching migration. The Professional Geographer, 51(1), 50-59.

Findlay, A., McCollum, D., Shubin, S., Apsite, E., \& Krisjane, Z. (2013). The role of recruitment agencies in imagining and producing the 'good'migrant. Social \& Cultural Geography, 14(2): 145-167.

Flum H, Cinnamon G (2011) Immigration and the integration of citizenship, identity and career: The case of Ethiopian immigration to Israel. Journal of Vocational Behavior 78: 372380.

Franck A, Spehar A (2010) Women's labour migration in the context of globalisation. WIDE Available at: http://www.wide-network.org

Fudge, J, (2012) Precarious migrant status and precarious employment: The paradox of International Rights for Migrant Workers. Comparative Labour Law \& Policy Journal, 34, 95-132.

Gammeltoft-Hansen T, Nyberg Sorensen N (2013) The Migration Industry and the Commercialization of International Migration. Routledge: New York.

Garapich M (2008) The Migration Industry and Civil Society: Polish Immigrants in the United Kingdom Before and After EU Enlargement. Journal of Ethnic and Migration Studies 34(5): 735-52.

Goldring, L., Berinstein, C., \& Bernhard, J. K. (2009) Institutionalizing precarious migratory status in Canada. Citizenship Studies, 13(3): 239-265.

Goss, J., \& Lindquist, B. (1995) Conceptualizing international labor migration: a structuration perspective. International Migration Review, 317-351. 
Government of Canada (2014) Determined your eligibility - Federal skilled workers. Available at: http://www.cic.gc.ca/english/immigrate/skilled/apply-who.asp

Groutsis, D., van den Broek, D. \& Harvey, W. S. (2015) Transformations in Network Governance: The Case of Migration Intermediaries. Journal of Ethnic and Migration Studies, (ahead-of-print), 1-19.

Hawthorne, L. (2012) Health workforce migration to Australia: policy trends and outcomes 2004-2010.

Hondagneu-Sotelo P (2001) Domestica: Immigrant Workers Cleaning and Caring in the Shadows of Affluence. Berkeley: University of California Press.

Jokinen, A., Ollus, N., \& Viuhko, M. (2011) Work on Any Terms: Trafficking for Forced Labour and Exploitation of Migrant Workers in Finland. Trafficking for Forced Labour and Labour Exploitation in Finland, Poland and Estonia. HEUNI Report Series, (68), 31-164.

International Organization for Migration. (2008) World Migration 2008: Managing Labor Mobility in the Evolving Global Economy. IOM World Migration Report Series. Volume 4. Geneva: IOM.

Kyle D, Liang Z (2001) Migration merchants: human smuggling from Ecuador and China to the United States. In: Guiraudon V and Joppke C. (eds) Controlling a new migration world. London: Routledge, 200-221

Lindquist, J., Xiang, B., \& Yeoh, B. S. (2012) Opening the black box of migration: Brokers, the organization of transnational mobility and the changing political economy in Asia. Pacific Affairs, 85(1), 7-19. 
MacKenzie R, Forde C (2009) The rhetoric of the 'good worker' versus the realities of employers use and the experiences of migrant workers. Work, Employment and Society 23(1): 142-159.

Massey D, and Espinosa K (1997) What's Driving Mexico-U.S. Migration? A Theoretical, Empirical, and Policy Analysis. The American Journal of Sociology 102(4): 939-999.

Massey DS, Arango J, Hugo G, Kouaouchi A, Pellegrino A and Taylor J (1998) Worlds in Motion. Oxford: Oxford University Press.

Manpower Group (2012). Available at: http://www.manpowergroup.com/about/about.cfm

McLaughlan G, Salt J (2002) Migration Policies Towards Highly Skilled Foreign Workers: Report to the Home Office. Migration Research Unit Geography Department: University College London.

Moreno-Fontes Chammartin G (2008) Migration, Gender Equality and Development. International Labor Organization. Available at: http://www.icgmd.info/docs/paper_ilo.pdf

Newland K, Agunias DR (2007) Circular Migration and Development: Trends, Policy Routes and Ways Forward. Washington: Migration Policy Institute.

Nyberg Sorensen N \& Gammeltoft-Hansen T, (2013) 'Introduction’ In: Gammeltoft-Hansen T, Nyberg Sorensen $\mathrm{N}$ (eds) The Migration Industry and the Commercialization of International Migration. Routledge: New York, 1-23.

OECD (2013) Recruiting Immigrant Workers: Germany. OECD Publishing. Available at: http://dx.doi.org/10.1787/9789264189034-en.

Papademetriou DG, Sumption M (2011) Rethinking Points Systems and Employer-Selected Immigration. Washington DC: Migration Policy Institute 
Papademetriou DG, Somerville W and Tanaka H (2008) Hybrid Immigrant-Selection Systems: The Next Generation of Economic Migration Schemes. Washington DC: Migration Policy Institute.

Peck J, Theodore N and Ward K (2005) Constructing markets for temporary labour: employment liberalization and the internationalization of the staffing industry. Global Networks 5: 3-26.

Pillinger J (2102) International Migration and Women Health and Social Care Workers Program, Quality healthcare and workers on the move. Public Services International: Australia national report. Available at: http://www.worldpsi.org/sites/default/files/documents/research/en_migrationhealthsocial_southafricareport_se pt2011.pdf

Portes A (1995) Economic sociology and the sociology of immigration: A conceptual Overview. In: Portes A. (ed) The Economic Sociology of Migration. New York: Russell Sage Foundation, 1-41.

Poros M (2001) The role of immigrant networks in linking local labor markets: The case of Asian Indian migration to New York and London. Global Networks 1(3): 243-59.

Purkayastha B (2005) Skilled migration and cumulative disadvantage: the case of highly qualified Asian Indian immigrant women in the US. Geoforum, 36: 181-96.

Purcell J, Purcell K and Tailby S. (2004) Temporary Work Agencies: Here Today, Gone Tomorrow? British Journal of Industrial Relations 42(4): 705-725.

Salt, J. (1983) High level manpower movements in Northwest Europe and the role of careers: an explanatory framework. International Migration Review, 17(4): 633-652. 
Salt J, Stein J (1997) Migration as a business: the case of trafficking. International Migration 35(4): 467-489.

Sporton D (2013) 'They Control My Life': the Role of Local Recruitment Agencies in East European Migration to the UK. Population, Space and Place 19(5): 443-458.

Taylor-Nicholson, E Paoletti, S, Sijapati, B., \& Farbenblum, B. (2014a) A Risky Business: Accountability of Manpower Agencies in Nepal, Centre for the Study of Labour and Mobility, Policy Brief, No 3, June 2014.

Taylor-Nicholson, E Paoletti, S, Sijapati, B., \& Farbenblum, B. (2014b) Labor Migration Agents: Regulation, Accountability and Alternatives, Centre for the Study of Labour and Mobility, Policy Brief, No 5, June 2014.

Tilly C (1990) Transplanted networks. In: Yans-MacLoughlin V. (ed) Immigration Reconsidered. New York: Oxford University Press, 79-95

Urry J (2007) Mobilities. London: Polity.

van den Broek, D., Groutsis, D and Wright, C (2013) Employer-Sponsored Migration: Mechanism of Labour Market Efficiency or Worker Vulnerability? Global Interdisciplinary Conference, UCLA and ADAPT University of Bergamo, May 31- June 1.

Van Hear N (2004) I went as far as my money would take me': conflict, forced migration and class. Centre on Migration, Policy and Society Working Paper No. 6 University of Oxford WP-04-06. Available at: http://www.compas.ox.ac.uk/fileadmin/files/Publications/working_papers/WP_2004/WP0406 . $\mathrm{pdf}$ 
Vosko, L. (2011) Out of the Shadows? The Non-Binding Multilateral Framework on Migration (2006) and Prospects for Using International Labour Migration to Forge Global Labour Market Membership. The Idea of Labour Law, 365-184.

Wright, C. F. (2012) Immigration policy and market institutions in liberal market economies. Industrial Relations Journal, 43(2): 110-136.

Woolfson, C., Fudge, J., \& Thörnqvist, C. (2014) Migrant precarity and future challenges to labour standards in Sweden. Economic and Industrial Democracy, 35(4): 695-715.

Xiang B (2001) Structuration of Indian information technology professionals migration to Australia: An ethnographic study. International Migration 39(5): 73-88.

Xiang, B. (2012) Predatory Princes and Princely Peddlers: The state and international labour migration intermediaries in China. Pacific Affairs, 85(1), 47-68.

Yamamoto S (2008) Intermediaries and Immigration in the United States. Unpublished PhD Dissertation University of Illinois at Urbana-Champaign.

Zurn, P., \& Dumont, J. C. (2008) Health workforce and international migration: can New Zealand compete? 
Di van den Broek is an Associate Professor in Work \& Organisational Studies at the University of Sydney Business School in Australia and is the co-Convenor of the Managing Global Migration Research Group at the School of Business. Her research interests include work and employment, particularly understanding why and how people cross the globe to secure skilled work, and why they put particular clothes on when they go to work.

William Harvey is Senior Lecturer and Director of Research in Organisation Studies at the University of Exeter Business School. His research interests include skilled migration, corporate reputation, leadership, talent management, business and political elites and social networks.

Dimitria Groutsis is Senior Lecturer in the Business School at the University of Sydney. Her research focuses on high and low skilled labour mobility, the history of migration management and diversity management with a focus on race and ethnicity. 